Article

\title{
Fatty Acid Composition of Dairy Milk: A Case Study Comparing Once- and Twice-a-Day Milking of Pasture-Fed Cows at Different Stages of Lactation
}

\author{
Inthujaa Sanjayaranj 1,2,*, Nicolas Lopez-Villalobos ${ }^{1}$ (D) Hugh T. Blair ${ }^{1}$, Patrick W. M. Janssen ${ }^{3}$, \\ Stephen E. Holroyd ${ }^{4}$ and Alastair K. H. MacGibbon ${ }^{4}{ }^{\mathbb{D}}$ \\ 1 Animal Science, School of Agriculture and Environment, Massey University, Private Bag 11 222, \\ Palmerston North 4442, New Zealand; n.lopez-Villalobos@massey.ac.nz (N.L.-V.); \\ h.blair@massey.ac.nz (H.T.B.) \\ 2 Department of Animal Science, Faculty of Agriculture, Eastern University, Chenkaladi 30350, Sri Lanka \\ 3 School of Food and Advanced Technology, Massey University, Private Bag 11 222, \\ Palmerston North 4442, New Zealand; p.janssen@massey.ac.nz \\ 4 Fonterra Research and Development Centre, Private Bag 11029, Palmerston North 4442, New Zealand; \\ steve.holroyd@fonterra.com (S.E.H.); alastair.macgibbon@fonterra.com (A.K.H.M.) \\ * Correspondence: i.sanjayaranj@massey.ac.nz
}

check for updates

Citation: Sanjayaranj, I.; Lopez-Villalobos, N.; Blair, H.T.; Janssen, P.W.M.; Holroyd, S.E.; MacGibbon, A.K.H. Fatty Acid Composition of Dairy Milk: A Case Study Comparing Once- and Twice-a-Day Milking of Pasture-Fed Cows at Different Stages of Lactation. Dairy 2022, 3, 174-189. https:// doi.org/10.3390/dairy3010014

Received: 4 November 2021 Accepted: 2 February 2022 Published: 1 March 2022

Publisher's Note: MDPI stays neutral with regard to jurisdictional claims in published maps and institutional affiliations.

Copyright: (C) 2022 by the authors. Licensee MDPI, Basel, Switzerland. This article is an open access article distributed under the terms and conditions of the Creative Commons Attribution (CC BY) license (https:// creativecommons.org/licenses/by/ $4.0 /)$.

\begin{abstract}
In this case study, we compared the gross composition and fatty acid (FA) composition of milk from cows milked once a day (OAD) and twice a day (TAD) at different stages of lactation in real farm conditions with no control on feed. Seventy-two cows from a OAD milking herd and 181 cows from a TAD milking herd were sampled in early, mid and late lactation. Calibration equations were developed to enable the prediction of proportions of individual FAs using mid-infrared (MIR) spectroscopy. Cows milked OAD produced $25 \%$ lower daily milk yield (MY) compared to cows milked TAD. Percentages of fat and protein were $21 \%$ and $9 \%$ higher in cows milked OAD compared to cows milked TAD, respectively. The proportion of saturated fatty acids (SFA) (molecules with unbranched hydrocarbon chains and all single bonds) was significantly lower, while the proportions of de novo synthesised FAs from C8:0 to C14:0 were significantly higher, in cows milked OAD compared to cows milked TAD. OAD milking improved the energy balance of cows, which led to higher proportions of de novo synthesised FAs and lower proportions of long-chain fatty acids (16:0 and above). The proportion of SFA was significantly higher in mid lactation (ML) compared to early lactation (EL) and late lactation (LL) in cows milked OAD and TAD. In EL, the proportions of C4:0 to C12:0 FAs in cows milked OAD were significantly higher compared to the cows milked TAD due to the improved energy status of cows milked OAD. Understanding the proportions of individual FAs in cows milked OAD and TAD will enable further studies on milk fat characteristics and on butter hardness and coagulation properties of milk.
\end{abstract}

Keywords: fatty acid; milk composition; milking frequency; stage of lactation; dairy cow; New Zealand

\section{Introduction}

Milk composition affects the yield and quality of dairy products [1]. Fat and protein are major components in milk which influence the final yield and quality of dairy products, especially cheese [2,3] and butter [4]. Milk fat is mainly composed of fatty acids (FAs), with cow milk comprising 70\% saturated fatty acids (SFA) and 30\% unsaturated fatty acids (UFA) [5]. The content of different FAs in milk affects the quality of milk and dairy products. FAs in the milk, such as C8:0, C10:0, C12:0, C18:1 and C18:2, affect the depth of curd formed during cheese making [2]. The variation in milk composition and fatty acid composition is caused by several factors, including genetics, breed, feed, season, stage of lactation and age of cows $[3,6,7]$. UFA concentration is lower in mid lactation compared to early and late 
lactation [8-10]. Milk from late lactation cows could have different processing properties compared to milk from early and mid-lactation cows [11].

In New Zealand, dairy farmers are paid for the quantity of milk fat and protein with a penalty for milk volume. Traditionally, cows are milked twice a day (TAD). Over the last two decades, some farmers have adopted once-a-day (OAD) milking for the whole season or part of the season due to several benefits for the farmer and for the cow [12]. Once-a-day milking reduces feed, labour and management costs, improves labour and farm efficiency, and provides farmers an alternative employment option [13,14]. The reproductive performance of cows milked OAD is significantly improved compared to cows milked TAD [15,16]. However, OAD milking reduces the yields of milk, fat and protein, which are the main concerns for farmers interested in practicing OAD milking [14]. Once-a-day milking could modify the composition of milk as milk synthesis and milk secretion are likely to be reduced by OAD milking in dairy cows [17]. Fat and protein content increased, and lactose content decreased during OAD milking in both short [13] and full $[15,16]$ lactation studies. The changes in the milk composition could influence the processing characteristics of the milk. OAD milking tends to affect cheese coagulation properties by increasing rennet clotting time and curd firming time [18] or improving cured firmness [19], although one study showed no change in these properties [20].

There have been no studies exploring the effect of milking frequency (MF) on milk fat composition. Therefore, the objective of this case study was to compare the gross composition and FA composition of milk from cows milked OAD and TAD at different stages of lactation in real farm conditions with no control on feed.

\section{Materials and Methods}

\subsection{Farm Data}

This study was conducted at Massey University, Palmerston North dairy farms from July 2020 to March 2021. The farms are located in the lower North Island of New Zealand (longitude $175^{\circ}$, latitude $-40^{\circ}$ ), adjacent to each other, and therefore cows experienced the same weather conditions but different management systems for feeding and milk harvesting.

The Massey University No. 1 dairy farm is managed as a low-input system, with cows milked once a day throughout the season. The stocking rate of the farm is 2.4 cows/ha, with cows mainly grazing on fresh ryegrass (Lolium perenne)/white clover (Trifolium repens) pasture, with limited supplements and periodic allocation of grazing crops. Cows were milked daily at $6.30 \mathrm{am}$. After milking each morning, all cows were allocated a fresh strip of pasture or crops as a single herd.

The Massey University No. 4 dairy farm is managed as a high-input system, with cows milked twice a day over the entire lactation period. The stocking rate is 2.6 cows/ha. Ryegrass-white clover pasture is given as a main feed source, but with a higher level of supplementation than the No. 1 dairy farm. Cows were milked daily at 5.30 am and $2.30 \mathrm{pm}$. After milking each morning and evening, all cows were allocated a fresh strip of pasture or crop as a single herd. The approximate values of diet composition and chemical composition of feed given to cows in both farms during the study period are shown in Table 1.

The limitation of this study was the confounding effect of feed and MF, there was no control practiced in this study. The feed provided during the experimental period was not identical. The cows milked TAD were fed slightly higher supplements than cows milked OAD. 
Table 1. Dietary and chemical composition of feed offered at the No. 1 and No. 4 dairy farms during the sampling periods (early, mid and late lactation) in the 2020-2021 production season.

\begin{tabular}{|c|c|c|c|c|c|c|}
\hline \multirow{2}{*}{$\begin{array}{c}\text { Farm } \\
\text { Lactation Stage }\end{array}$} & \multicolumn{3}{|c|}{ No. 1 Dairy Farm (OAD ${ }^{11}$ ) } & \multicolumn{3}{|c|}{ No. 4 Dairy Farm $\left(\right.$ TAD $^{12}$ ) } \\
\hline & $\begin{array}{c}\text { Early } \\
\text { (September) }\end{array}$ & $\begin{array}{c}\text { Mid } \\
\text { (December) }\end{array}$ & $\begin{array}{c}\text { Late } \\
\text { (March) }\end{array}$ & $\begin{array}{c}\text { Early } \\
\text { (September) }\end{array}$ & $\begin{array}{c}\text { Mid } \\
\text { (December) }\end{array}$ & $\begin{array}{c}\text { Late } \\
\text { (March) }\end{array}$ \\
\hline \multicolumn{7}{|l|}{$\begin{array}{l}\text { Diet composition } \\
\text { (kg DM/cow/day) }\end{array}$} \\
\hline Pasture & 8.0 & 12.0 & 4.5 & 17.0 & 17.0 & 10.0 \\
\hline Herb mix crop ${ }^{1}$ & 4.0 & 4.0 & 3.0 & - & - & - \\
\hline Maize silage & 1.0 & - & - & 5.0 & 5.0 & 2.0 \\
\hline $\mathrm{DDG}^{2}$ & 1.5 & - & - & - & 1.0 & - \\
\hline Tapioca pellets & 1.5 & - & 1.5 & - & - & - \\
\hline Concentrate $^{3}$ & - & - & 2.0 & 4.0 & - & 1.0 \\
\hline Dry roughage $^{4}$ & - & - & - & 0.2 & - & 1.0 \\
\hline Baleage $^{5}$ & - & - & 4.0 & - & 1.0 & 10 \\
\hline \multicolumn{7}{|c|}{ Diet chemical composition } \\
\hline $\mathrm{ME}^{6} \mathrm{MJ} / \mathrm{kg} \mathrm{DM}$ & 11.89 & 12.12 & 9.98 & 11.36 & 10.58 & 11.28 \\
\hline $\mathrm{CP}^{7} \mathrm{~g} / 100 \mathrm{~g} \mathrm{DM}$ & 20.08 & 19.48 & 21.91 & 19.49 & 19.08 & 21.27 \\
\hline $\mathrm{NDF}^{8} \mathrm{~g} / 100 \mathrm{~g} \mathrm{DM}$ & 38.18 & 38.66 & 39.88 & 44.13 & 43.48 & 45.69 \\
\hline $\mathrm{ADF}^{9} \mathrm{~g} / 100 \mathrm{~g} \mathrm{DM}$ & 20.94 & 20.38 & 26.00 & 20.71 & 23.60 & 25.40 \\
\hline $\mathrm{SSS}^{10} \mathrm{~g} / 100 \mathrm{~g} \mathrm{DM}$ & 16.77 & 14.11 & 8.79 & 19.13 & 17.55 & 8.59 \\
\hline Lipid g/100 g DM & 4.08 & 4.69 & 4.54 & 4.40 & 4.09 & 4.77 \\
\hline
\end{tabular}

${ }^{1}$ Comprises chicory (Cichorium intybus), red clover (Trifolium pratense), and plantain (Plantago lanceolata); ${ }^{2}$ distillers dried grain; ${ }^{3}$ grain-based concentrate; ${ }^{4}$ hay and straw; ${ }^{5}$ Lucerne baleage in the No. 1 dairy farm and grass baleage in the No. 4 dairy farm. $\mathrm{DM}=$ dry matter. ${ }^{6} \mathrm{ME}=$ metabolisable energy $;{ }^{7} \mathrm{CP}=$ crude protein; ${ }^{8} \mathrm{NDF}=$ neutral detergent fibre; ${ }^{9} \mathrm{ADF}=$ acid detergent fibre; ${ }^{10} \mathrm{SSS}=$ soluble sugars and starch; ${ }^{11} \mathrm{OAD}=$ once-a-day milking; $12 \mathrm{TAD}=$ twice-a-day milking; baleage is partly dried forage, with $45-55 \%$ moisture and is baled and wrapped with at least 6 layers of $0.025 \mathrm{~mm}$ plastic.

\subsection{Sample Collection}

Milk sample collection was conducted on both farms during the 2020-2021 production season during early (EL, September), mid (ML, December) and late (LL, March) lactation. Composite milk samples of $50 \mathrm{~mL}$ were collected using Waikato milk flow meters from 72 No. 1 dairy farm cows and 181 No. 4 dairy farm cows. The cows from the No. 1 dairy farm consisted of 39 Holstein-Friesian $(\mathrm{F})$ and 33 Holstein-Friesian $\times$ Jersey $(\mathrm{F} \times \mathrm{J})$ crossbred cows. The cows from the No. 4 dairy farm herd consisted of $101 \mathrm{~F}$ and $80 \mathrm{~F} \times \mathrm{J}$ crossbred cows. All the cows sampled from the two farms were 1st and 2nd lactation cows. Milk samples were refrigerated at $0-4{ }^{\circ} \mathrm{C}$ until analysis, which was carried out within two days of each sampling in September, December, and March.

\subsection{Milk Composition and Fatty Acid Analysis}

Gross composition and individual FAs were determined using Milkoscan FT1 (Foss Analytical, Hillerød, Denmark). A total of 115 milk samples were collected during the milking season 2020-2021 from 1st and 2nd lactation $\mathrm{F}$ and $\mathrm{F} \times \mathrm{J}$ crossbred cows during EL (mid-September). One part of the 115 individual milk samples was analysed for proportions of FAs by fatty acid methyl ester analysis using gas chromatography (GC) [21] with Shimadzu GC-2010 plus. The remaining part of the milk samples was analysed for FAs in Milkoscan FT1 (Foss Analytical, Hillerød, Denmark). Calibration equations for individual FAs were developed using FTIR calibrator software (Foss Analytical, Hillerød, Denmark). The calibration equations were created using 95 samples for training and 20 samples for validation. The coefficient of determination $\left(R^{2}\right)$ values for all FA equations were more than 0.8 . The developed calibration equations were used to predict the proportions of induvial FAs of milk collected from 253 cows in EL, ML and LL using Milkoscan FT1 machine. Percentages of fat, protein and lactose were analysed using standard calibrations from Foss. The milk composition of samples collected evening and morning in TAD milking 
(No. 4 dairy farm) was analysed separately, and a weighted (by milk yield) average was used in analyses.

\subsection{Body Condition Score}

Body condition score (BCS) was measured during the 2020-2021 production season by a single research technician using a 10-point scale [22]. The BCS of each cow in each MF was recorded every month from calving to dry off date.

\subsection{Statistical Analysis}

Statistical analysis was performed using SAS version 9.4 (SAS Institute Inc., Cary, NC, USA). Least-squares means, and standard errors of the variables were obtained using the following linear mixed model using the MIXED procedure. In this study, feed was a confounding variable, and was not include in the model.

$$
Y_{i j k l m}=\mu+M_{i}+B_{j}\left(M_{i}\right)+L_{k}+S_{1}+M_{i l}+\beta_{1} d_{m}+\beta_{2} d_{m}^{2}+C_{m}+e_{i j k l m}
$$

$\mathrm{Y}_{\mathrm{ijklm}}$ is the observation for milk yield traits and composition traits for milking frequency $\mathrm{i}$, breed group $\mathrm{j}$, lactation number $\mathrm{k}$, stage of lactation 1 and cow $\mathrm{m}$.

$\mu$ is the population mean.

$M_{i}$ is the fixed effect of milking frequency $i(i=O A D$ and TAD).

$B_{j}\left(M_{i}\right)$ is the fixed effect of breed $j$ nested in milking frequency $i(j=F$ and $F \times J)$.

$\mathrm{L}_{\mathrm{k}}$ is the fixed effect of lactation number ( $\mathrm{k}=1$ st and 2nd lactation).

$\mathrm{S}_{\mathrm{l}}$ is the fixed effect of stage of lactation $\mathrm{k}(\mathrm{l}=$ early, mid and late $)$.

$\mathrm{MS}_{\mathrm{il}}$ is the fixed effect of interaction between milking frequency $\mathrm{i}$ and stage of lactation 1 .

$\beta_{1}$ is the regression coefficient associated with the linear effect of deviation from median calving date of cow $\mathrm{m}$.

$\beta_{2}$ is the regression coefficient associated with the quadratic effect of deviation from median calving date of cow $\mathrm{m}$.

$C_{m}$ is the random effect of cow $m(m=1,2, \ldots 253)$ assumed with mean zero and variance ${ }_{c}^{2}$.

$\mathrm{e}_{\mathrm{ijklm}}$ is the residual random error assumed with mean zero and variance ${ }_{\mathbf{e}}^{2}$.

Least-squares means and standard errors for MF and combinations of MFs and stages of lactation were obtained and used for multiple mean comparisons using Fisher's least significant difference $t_{i j}=\left(\bar{y}_{i}-\bar{y}_{j}\right) / \hat{\sigma}_{i j}$, where $i$ and $j$ are subscripts for two least squares either for each milking frequency or combination of milking frequency and stage of lactation, and $\hat{\sigma}_{i j}$ is the square root of the estimated variance of $\bar{y}_{i}-\bar{y}_{j}$ calculated as $\hat{\sigma}_{i j}^{2}=s^{2}\left(1 / w_{i}+1 / w_{j}\right)$, where $w_{i}$ and $w_{j}$ are the sums of the weights in groups $i$ and $j$. If $\left|\bar{y}_{i}-\bar{y}_{j}\right| \geq t(\alpha ; v) \sqrt{\hat{\sigma}_{i j}^{2}}$ then the least-squares means were declared significantly different. In this last equation, the right-hand side is Fisher's least significant difference, with $t(\alpha ; v)$ being the two-tailed critical value from Student's $t$ distribution with a significant level $\alpha$ and with a $v$ degree of freedom of the mean square of the error. Significant differences were declared at $p<0.05$. Monthly records of BCS, from calving to dry off, of each cow in each MF were used to model BCS curves with a third-order polynomial.

\section{Results}

Descriptive statistics of daily yields of milk components, gross milk composition and fatty acid composition of all the samples (regardless of MF and stage of lactation) analysed are presented in Table 2. 
Table 2. Descriptive statistics of daily yields of milk, fat, protein and lactose, gross milk composition and fatty acid composition of cows milked during the 2020-2021 production season.

\begin{tabular}{|c|c|c|c|c|c|c|}
\hline Variable & $N$ & Mean & SD & CV\% & Min & Max \\
\hline Milk yield (L/cow/day) & 755 & 18.15 & 5.73 & 31.6 & 4.60 & 39.50 \\
\hline Fat yield (kg/cow/day) & 755 & 0.85 & 0.28 & 32.4 & 0.26 & 5.22 \\
\hline Protein yield (kg/cow/day) & 755 & 0.68 & 0.17 & 25.4 & 0.21 & 1.54 \\
\hline Lactose yield (kg/cow/day) & 755 & 0.91 & 0.31 & 34.3 & 0.19 & 2.08 \\
\hline Fat $\%$ & 759 & 4.27 & 0.96 & 22.6 & 1.27 & 8.53 \\
\hline Protein $\%$ & 759 & 3.87 & 0.41 & 10.7 & 2.74 & 5.67 \\
\hline Lactose $\%$ & 759 & 4.97 & 0.26 & 5.2 & 4.07 & 5.51 \\
\hline \multicolumn{7}{|c|}{ Fatty Acid (\% of the total FA) } \\
\hline SFA $^{1}$ & 759 & 69.94 & 3.04 & 4.3 & 57.10 & 77.94 \\
\hline UFA $^{2}$ & 759 & 30.23 & 2.60 & 8.6 & 23.70 & 41.44 \\
\hline PUFA $^{3}$ & 759 & 2.94 & 0.45 & 15.2 & 1.49 & 4.40 \\
\hline C4:0 & 759 & 4.03 & 0.30 & 7.5 & 2.50 & 4.65 \\
\hline C6:0 & 759 & 2.81 & 0.22 & 7.8 & 1.37 & 3.31 \\
\hline C8:0 & 759 & 1.51 & 0.15 & 9.7 & 0.56 & 1.91 \\
\hline C10:0 & 759 & 3.40 & 0.42 & 12.2 & 0.93 & 4.83 \\
\hline $\mathrm{C} 12: 0$ & 759 & 3.80 & 0.35 & 9.3 & 2.17 & 5.06 \\
\hline C14:0 & 759 & 12.68 & 1.24 & 9.8 & 7.14 & 15.33 \\
\hline C16:0 & 759 & 31.89 & 2.46 & 7.7 & 24.40 & 39.81 \\
\hline C18:0 & 759 & 13.04 & 1.42 & 10.9 & 7.87 & 22.23 \\
\hline C18:0 cis-9 & 759 & 20.31 & 2.70 & 13.3 & 14.75 & 32.52 \\
\hline Omega6 & 759 & 1.59 & 0.36 & 22.8 & 0.37 & 2.77 \\
\hline SCFA $^{4}$ & 759 & 8.35 & 0.61 & 7.4 & 4.43 & 9.71 \\
\hline MCFA $^{5}$ & 759 & 19.89 & 1.76 & 8.8 & 11.46 & 24.41 \\
\hline LCFA $^{6}$ & 759 & 66.83 & 2.57 & 3.9 & 59.12 & 82.02 \\
\hline
\end{tabular}

${ }^{1} \mathrm{SFA}=$ saturated fatty acids; ${ }^{2} \mathrm{UFA}=$ unsaturated fatty acid; ${ }^{3} \mathrm{PUFA}=$ polyunsaturated fatty acids; ${ }^{4} \mathrm{SCFA}=$ shortchain fatty acids (sum of C4:0, C6:0 and C8:0); ${ }^{5}$ MCFA = medium-chain fatty acids (sum of C10:0, C12:0 and C14:0); ${ }^{6}$ LCFA = long-chain fatty acids (sum of C16:0, C18:0 and C18:0 cis-9 and Omega6).

Least-squares means and standard errors for the study variables for both MFs are presented in Table 3. The least-squares means were calculated for the entire season and weighted average by milk yield was used to calculate the milk composition of samples from cows milked TAD. Cows milked OAD produced 25\% less daily milk yield (MY), $13 \%$ less fat yield (FY), 16\% less protein yield (PY) and 28\% less lactose yield (LY) compared to cows milked TAD. Percentage of fat was $21 \%$ higher, and percentage of protein was $9 \%$ higher in cows milked OAD compared to cows milked TAD. Percentage of lactose was significantly lower in cows milked OAD compared to cows milked TAD. The proportion of SFA was lower in cows milked OAD compared to cows milked TAD, while the proportion of UFA in cows milked OAD was higher than in cows milked TAD. The proportion of PUFA was higher in cows milked OAD than in cows milked TAD. The proportions of short-chain fatty acids (SCFA) and long-chain fatty acids (LCFA) were significantly lower, and the proportion of medium-chain fatty acids (MCFA) was significantly higher in cows milked OAD.

Daily yields of milk, fat, protein, and lactose decreased from EL to LL (Figure 1) with TAD milking producing higher yields than OAD milking at all stages of lactation. Fat and protein percentages were higher $(p<0.05)$ in cows milked OAD than in cows milked in TAD, while lactose percentage was lower $(p<0.05)$ in cows milked OAD than cows milked TAD (Table 4 and Figure 2) throughout the season. Table 4 shows the least-squares means and the standard errors for all the study variables for three lactation stages in both MFs. Figures 1-4 show the pattern of daily yield traits, milk composition and proportions of some groups of FAs throughout the stages of lactation for each MF. 
Table 3. Least-squares means and standard errors of daily yields of milk, fat, protein and lactose, gross milk composition and fatty acid composition of cows milked once a day (OAD) and twice a day (TAD) during the 2020-2021 production season.

\begin{tabular}{|c|c|c|c|}
\hline \multirow{2}{*}{ Variable } & \multicolumn{2}{|c|}{ Milking Frequency } & \multirow{2}{*}{$p$-Value } \\
\hline & OAD & TAD & \\
\hline Milk yield (L/cow / day) & $14.98 \pm 0.3$ & $19.89 \pm 0.19$ & $<0.001$ \\
\hline Fat yield (kg/cow/day) & $0.78 \pm 0.02$ & $0.90 \pm 0.01$ & $<0.001$ \\
\hline Protein yield (kg/cow/day) & $0.61 \pm 0.01$ & $0.73 \pm 0.01$ & $<0.001$ \\
\hline Lactose yield (kg/cow/day) & $0.72 \pm 0.02$ & $1.00 \pm 0.01$ & $<0.001$ \\
\hline Fat $\%$ & $5.03 \pm 0.08$ & $3.99 \pm 0.05$ & $<0.001$ \\
\hline Protein \% & $4.12 \pm 0.03$ & $3.76 \pm 0.02$ & $<0.001$ \\
\hline Lactose $\%$ & $4.80 \pm 0.02$ & $5.02 \pm 0.01$ & $<0.001$ \\
\hline \multicolumn{4}{|l|}{ Fatty Acid ( $\%$ of the total FA) } \\
\hline SFA $^{1}$ & $69.47 \pm 0.21$ & $70.47 \pm 0.13$ & $<0.001$ \\
\hline UFA $^{2}$ & $31.03 \pm 0.17$ & $29.59 \pm 0.11$ & $<0.001$ \\
\hline PUFA $^{3}$ & $3.11 \pm 0.02$ & $2.83 \pm 0.02$ & $<0.001$ \\
\hline C4:0 & $3.83 \pm 0.02$ & $4.12 \pm 0.01$ & $<0.001$ \\
\hline C6:0 & $2.76 \pm 0.01$ & $2.84 \pm 0.01$ & $<0.001$ \\
\hline $\mathrm{C} 8: 0$ & $1.53 \pm 0.01$ & $1.51 \pm 0.01$ & 0.0190 \\
\hline C10:0 & $3.57 \pm 0.03$ & $3.36 \pm 0.02$ & $<0.001$ \\
\hline $\mathrm{C} 12: 0$ & $4.00 \pm 0.02$ & $3.74 \pm 0.02$ & $<0.001$ \\
\hline C14:0 & $12.83 \pm 0.08$ & $12.72 \pm 0.05$ & 0.2493 \\
\hline C16:0 & $31.31 \pm 0.18$ & $32.39 \pm 0.12$ & $<0.001$ \\
\hline C18:0 & $12.62 \pm 0.11$ & $13.24 \pm 0.07$ & $<0.001$ \\
\hline C18:0 cis-9 & $19.9 \pm 0.17$ & $20.21 \pm 0.11$ & 0.1310 \\
\hline Omega6 & $1.67 \pm 0.02$ & $1.53 \pm 0.01$ & $<0.001$ \\
\hline SCFA $^{4}$ & $8.12 \pm 0.04$ & $8.46 \pm 0.03$ & $<0.001$ \\
\hline MCFA $^{5}$ & $20.4 \pm 0.13$ & $19.82 \pm 0.08$ & 0.0002 \\
\hline LCFA $^{6}$ & $65.5 \pm 0.19$ & $67.37 \pm 0.12$ & $<0.001$ \\
\hline
\end{tabular}

${ }^{1}$ SFA $=$ saturated fatty acids $;{ }^{2}$ UFA $=$ unsaturated fatty acid $;{ }^{3}$ PUFA $=$ polyunsaturated fatty acid $;{ }^{4}$ SCFA $=$ short chain fatty acids (sum of C4:0, C6:0 and C8:0); ${ }^{5}$ MCFA = medium-chain fatty acids (sum of C10:0, C12:0 and C14:0); ${ }^{6}$ LCFA $=$ long-chain fatty acids (sum of C16:0, C18:0 and C18:0 cis-9 and Omega6).

Figure 3 shows the proportions of major groups of FAs at the three stages of lactation. In both MFs, the proportion of SFA was higher $(p<0.05)$ in ML compared to EL and LL. The proportion of UFA followed an opposite pattern to the proportion of SFA throughout lactation, with the proportion of PUFA being lowest $(p<0.05)$ in cows milked OAD and highest in cows milked TAD in ML.

The proportions of SCFA, MCFA and LCFA in milk fat at the three stages of lactation are shown in Figure 4 . Stage of lactation significantly $(p<0.05)$ affected the proportions of SCFA, MCFA and LCFA.

For cows milked OAD, the proportion of SCFA were higher in EL and then decreased throughout lactation, while the proportion of MCFA peaked in the ML. For cows milked TAD, the proportion of SCFA and MCFA increased from EL, peaked in ML and decreased in LL. In cows milked OAD, the, the proportion of LCFA increased from EL to LL; in cows milked TAD, the proportion of LCFA decreased from EL to LL.

Cows milked OAD had a higher BCS than cows milked TAD throughout the 20202021 production season (Figure 5). Cows milked OAD showed a slight change in BCS throughout lactation, whereas BCS decreased in cows milked TAD as lactation progressed. 
Table 4. Least-square means and standard errors of daily yields of milk, fat, protein and lactose, gross milk composition and fatty acid composition of cows milked once a day (OAD) and twice a day (TAD) in early, mid and late lactation during the 2020-2021 production season.

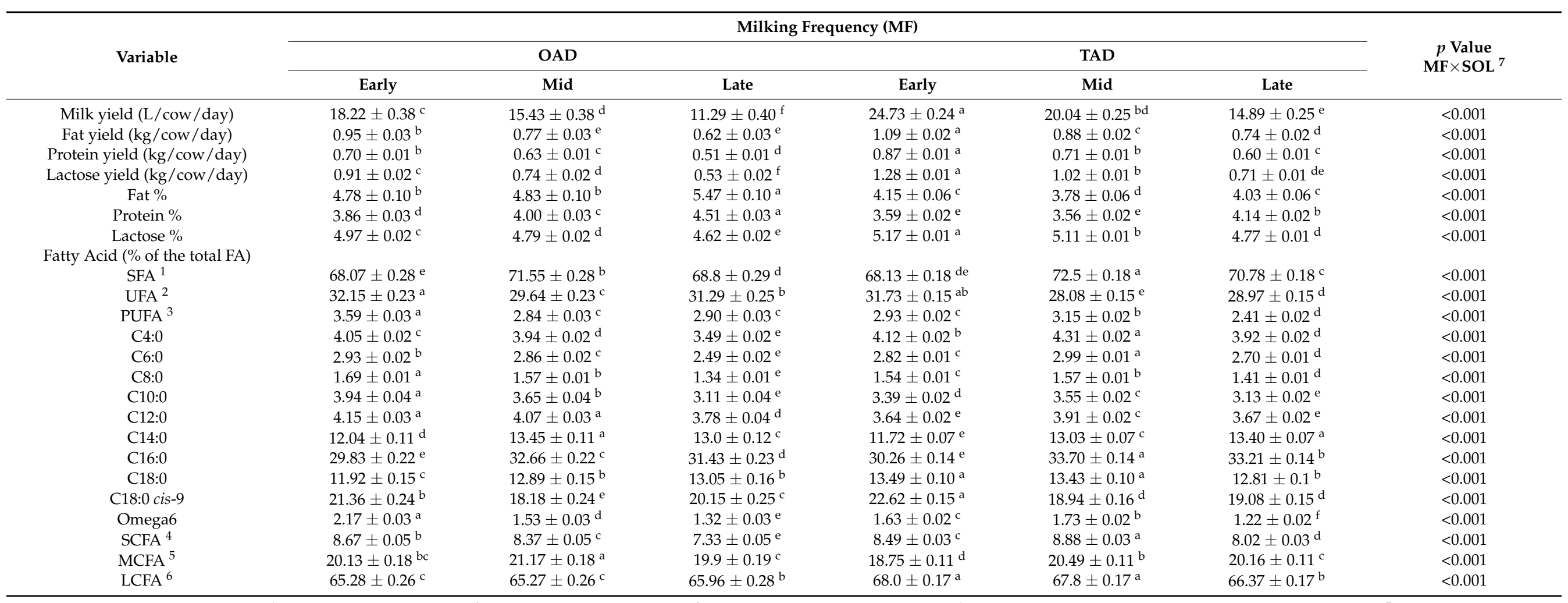

${ }^{1} \mathrm{SFA}=$ saturated fatty acids; ${ }^{2} \mathrm{UFA}=$ unsaturated fatty acid; ${ }^{3} \mathrm{PUFA}=$ polyunsaturated fatty acid $;{ }^{4}$ SCFA $=$ short-chain fatty acids (sum of C4:0, C6:0 and C8:0); ${ }^{5} \mathrm{MCFA}=$ medium-chain fatty acids (sum of C10:0, C12:0 and C14:0) ${ }^{6}$ LCFA = long-chain fatty acids (sum of C16:0, C18:0 and C18:0 cis-9 and Omega6). ${ }^{7}$ SOL $=$ stage of lactation (early, mid and late). ${ }^{a}, \mathrm{~b}, \mathrm{c}, \mathrm{d}, \mathrm{e}$ and ${ }^{\mathrm{f}}$ Means with different superscripts across milking frequency and stage of lactation are significantly different $(p<0.05)$. 

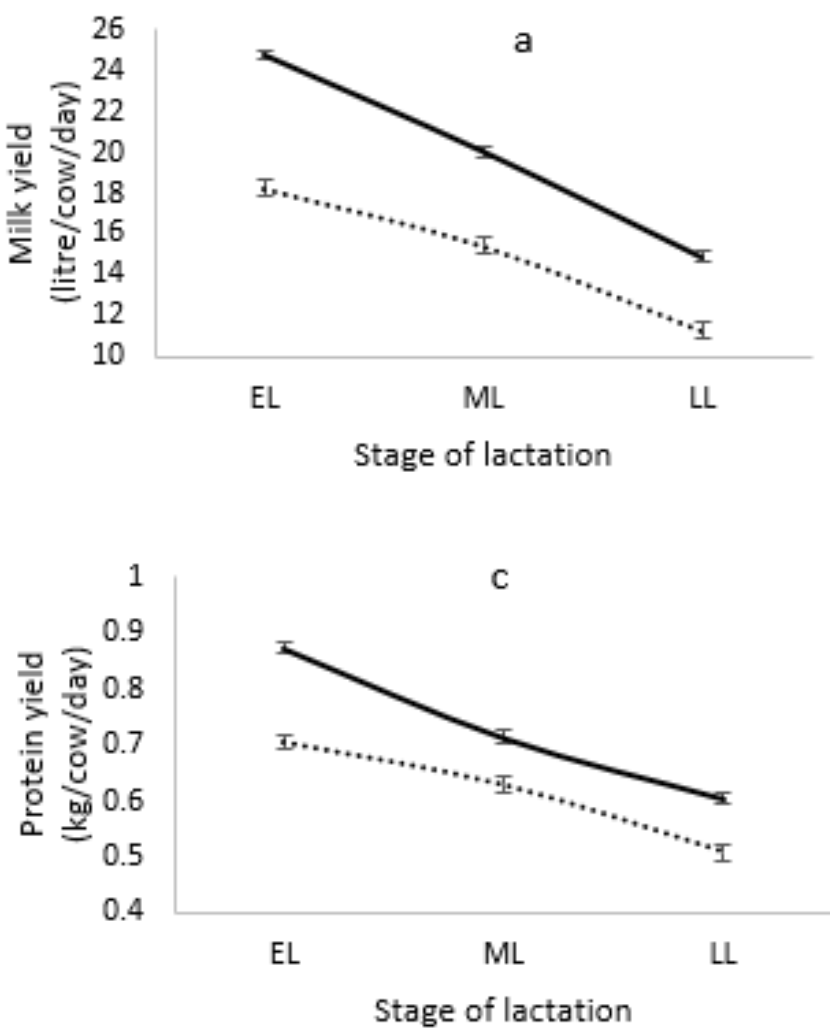
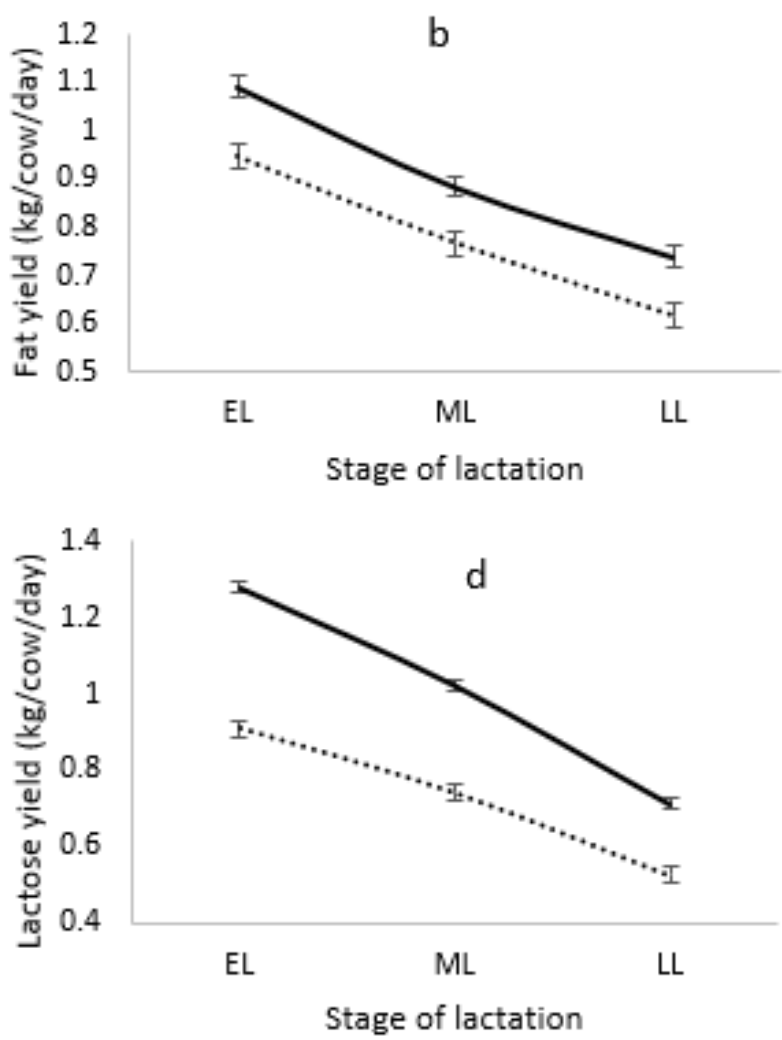

Figure 1. Daily yields of (a) milk, (b) fat, (c) protein and (d) lactose in cows milked OAD ( ... .) and TAD (-) during the production season 2020-2021. EL = early lactation ( $<90$ days); ML = mid lactation (90-180 days); $\mathrm{LL}=$ late lactation ( $>180$ days). The vertical bars show the standard errors. The $p$-values for the interaction between milking frequency and stage of lactation were $<0.0001$ for daily yield of milk, fat, protein and lactose.
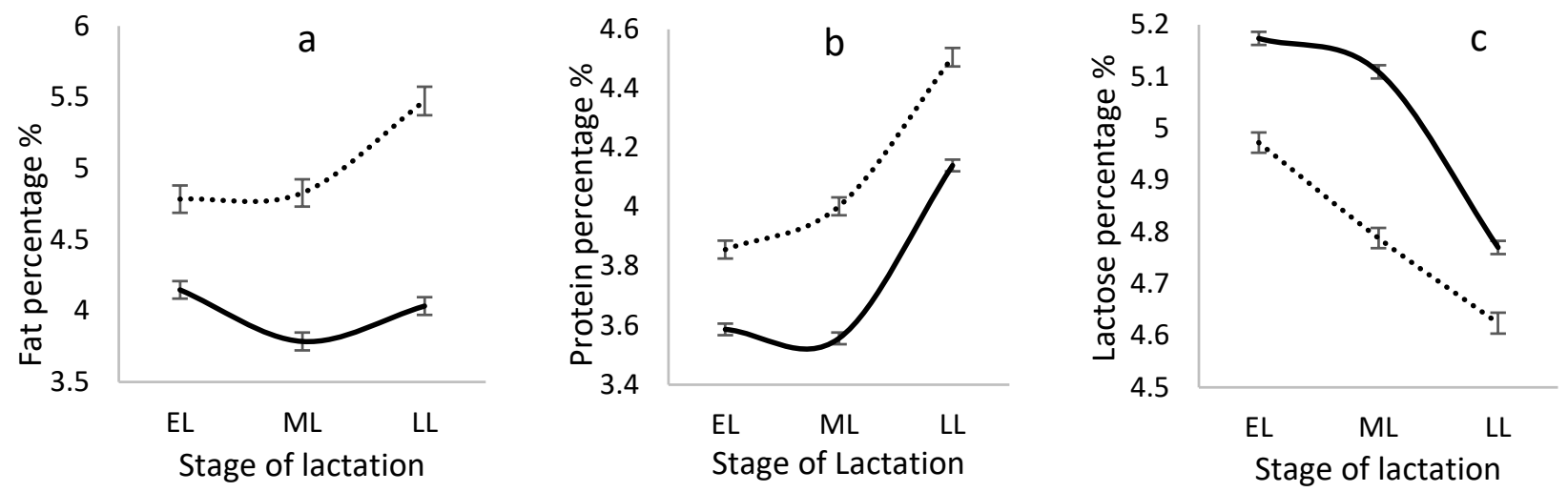

Figure 2. Percentage of (a) fat, (b) protein, and (c) lactose in cows milked OAD ( . . .) and TAD (一) during the production season 2020-2021. EL = early lactation ( $<90$ days); $\mathrm{ML}=$ mid lactation (90-180 days); $L L=$ late lactation (>180 days). The vertical bars show the standard errors. The $p$-values for the interaction between milking frequency and stage of lactation were $<0.0001$ for fat, protein and lactose percentages. 

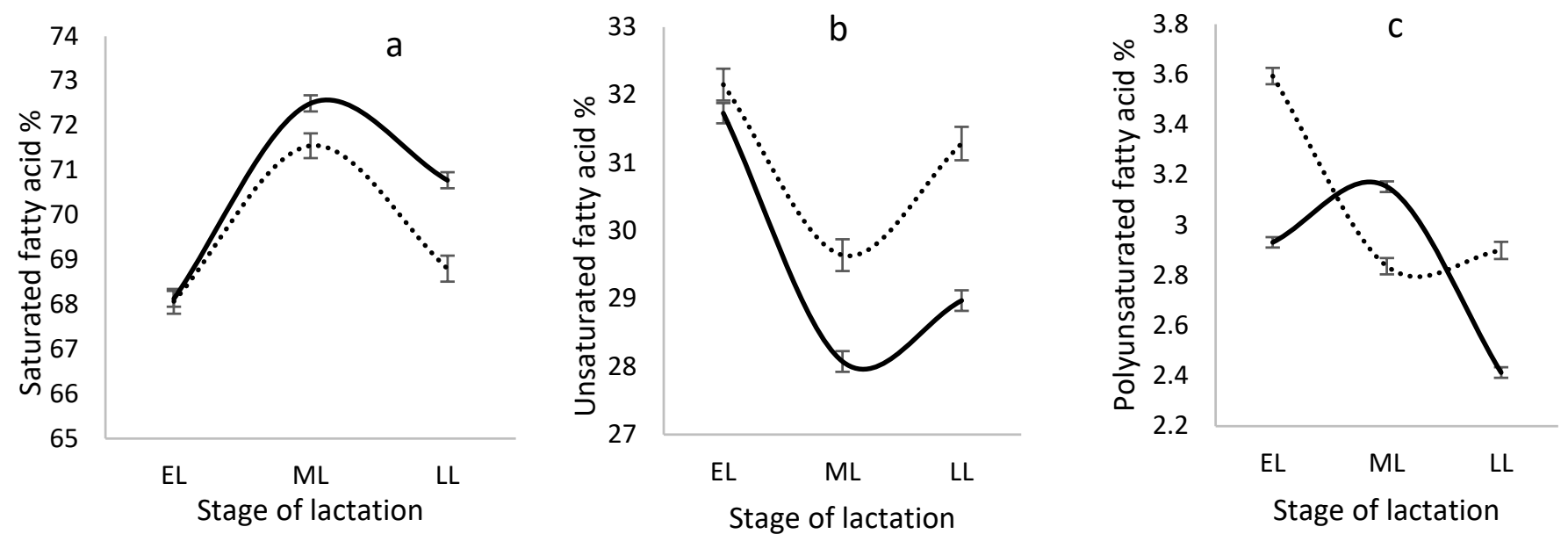

Figure 3. Proportion of (a) saturated fatty acids, (b) unsaturated fatty acids, and (c) polyunsaturated fattys in cows milked OAD ( . . .) and TAD (-) during the production season 2020-2021. EL = early lactation (<90 days); $\mathrm{ML}=$ mid lactation (90-180 days); $\mathrm{LL}=$ late lactation (>180 days). The vertical bars show the standard errors. The $p$-values for the interaction between milking frequency and stage of lactation were $<0.0001$ for saturated, unsaturated, and polyunsaturated fatty acids.

a

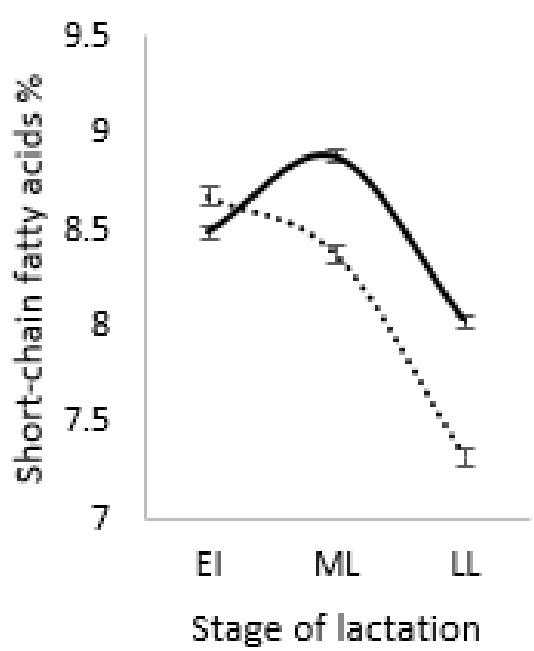

b

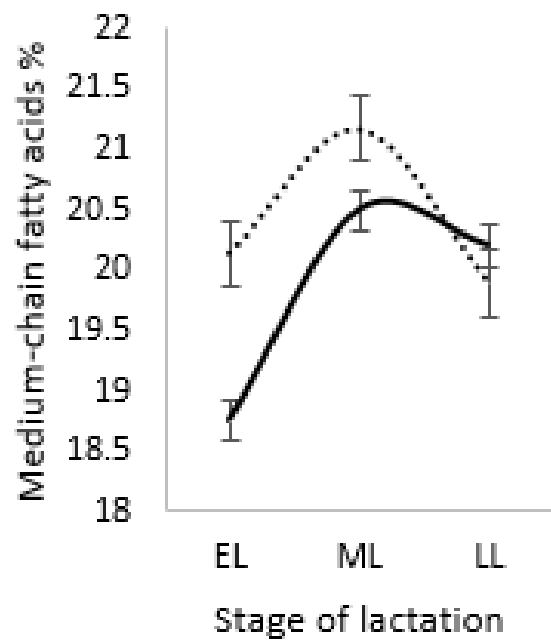

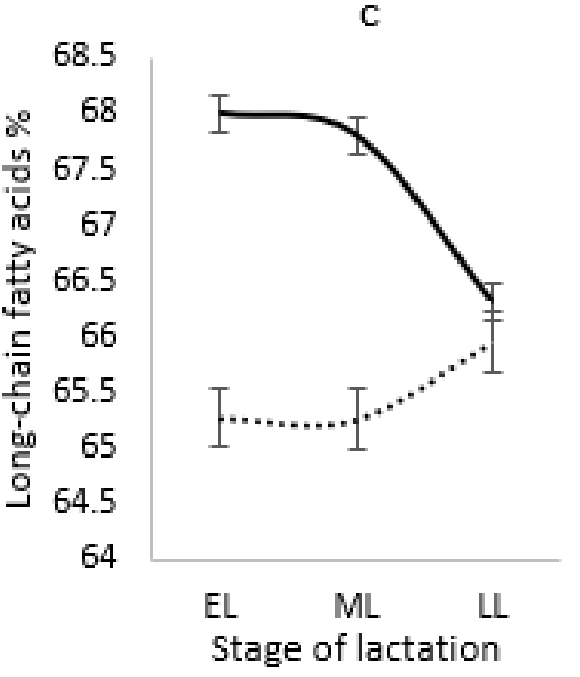

Figure 4. Proportion of (a) short-chain fatty acids, (b) medium-chain fatty acids, (c) and long-chain fatty acids in cows milked OAD ( . . . ) and TAD (-) during the production season 2020-2021. EL $=$ early lactation (<90 days); $\mathrm{ML}=$ mid lactation (90-180 days); $\mathrm{LL}=$ late lactation ( $>180$ days). The vertical bars show the standard errors. The $p$-values for the interaction between milking frequency and stage of lactation were $<0.0001$ for short-chain, medium-chain, and long-chain fatty acids. 


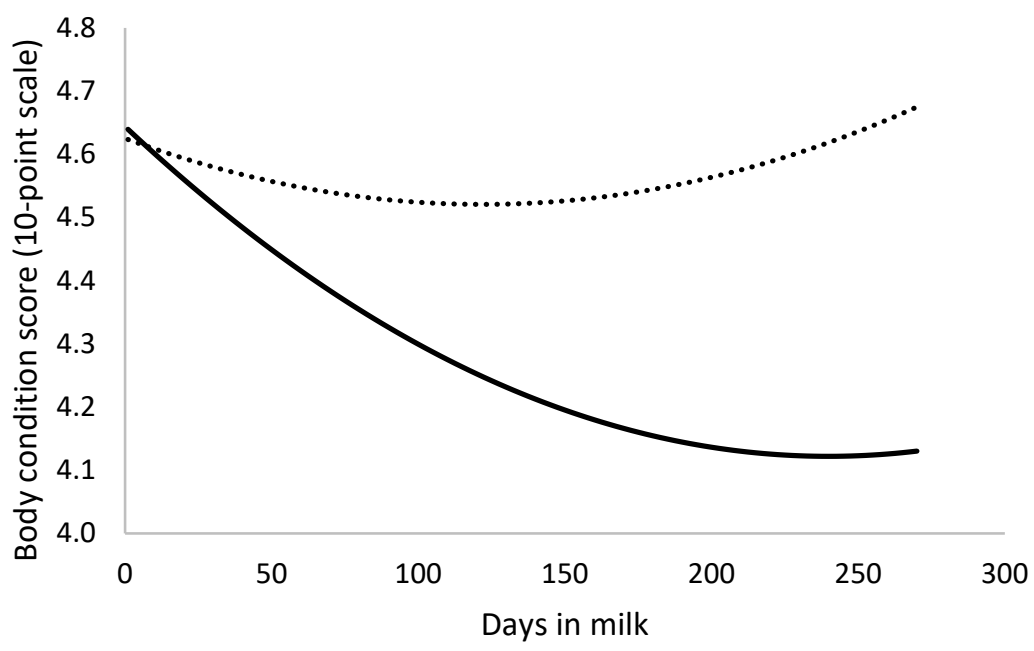

Figure 5. Body condition score of cows milked $\operatorname{OAD}(\ldots)$ and TAD ( $($ ) in a 10-point scale during the 2020-2021 production season.

\section{Discussion}

In New Zealand, TAD milking has been standard practice, but the percentage of farms milking TAD for the full season is now only $45 \%$ [23]. OAD milking is practiced either in the long term or in the short term to address adverse conditions, often feed shortages and/or to overcome staff shortages. It is accepted that OAD milking reduces cow milk yield. In this study, cows milked OAD produced lower daily milk yield compared to cows milked TAD. Lower MY led to higher percentages of fat and protein in milk from OAD milking. OAD milking also affected the FA profile of milk, with a lower proportion of SFA compared to cows milked TAD. Additionally, the BCS of cows milked OAD was higher than the BCS of cows milked TAD. The changes in the milk and its composition in the present study are consistent with Delamaire and Guinard-Flament [24] as well as Pulido et al. [25].

\subsection{The Effect of $O A D$ and TAD Milking on Milk Production and Gross Milk Composition}

OAD milking could reduce milk yield by a range of 22-50\% [14]. The reduction in daily MY could be driven by several physiological processes. Cows milked OAD also had a higher loss of udder capacity due to an increased rate of loss in secretory cells [26]. The physiological effects were likely caused by changes in gene expression, with Grala et al. [27] showing that the expression of milk synthesis genes was lower in cows milked $\mathrm{OAD}$ and Littlejohn et al. [28] found differences in the expressions of genes responsible for milk production such as apoptotic signalling, mechanical stress, epithelial tight junction synthesis and milk synthesis.

Higher percentages of fat and protein in cows milked OAD compared to cows milked TAD are in agreement with Cooper et al. [12], Rémond et al. [15], and Clark et al. [16]. In cows milked OAD, changes in the percentages of fat and protein may be due to the increased permeability of the tight junction between mammary epithelial cells leading to the exchange of milk and interstitial fluid [13,29]. This leakage of milk from mammary cells could create a higher concentration of milk solids [14]. Farr et al. [30] reported that in the long term, OAD milking inhibited the synthetic ability of the secretary tissues in the mammary gland and lowered the level of mammary enzymes. The lower concentration of lactose in cows milked OAD could be due to the efflux of lactose through the tight junction of the mammary gland [13]. Because lactose is an osmotically active particle which draws water, cows producing more milk will have a higher lactose concentration [13]. This is consistent with the effect observed in this study. 


\subsection{The Effect of $O A D$ and TAD Milking on Fatty Acid Composition}

The lower proportion of SFA in cows milked OAD, compared to cows milked TAD, is consistent with the findings of Dutreuil et al. [31], Ferlay et al. [32] and Pulido et al. [25]. The higher proportion of UFA in milk from cows milked OAD, compared to cows milked TAD agrees with Dutreuil et al. [31]. The lower proportion of SFA in cows milked OAD compared to cows milked TAD may be due to the lower mobilization of long-chain saturated fatty acids (C16:0 and C18:0) from adipose tissues into milk and lower synthesis of SCFA (C4:0 and C6:0). The synthesis and absorption of FAs are affected by the energy balance of cows $[9,33]$, which is linked to MF. Generally, in EL, cows have just calved and will be in negative energy balance. In this study, it seems that OAD milking allowed the cows to recover their energy balance faster. Cows milked OAD were likely to be in improved energy balance compared to cows milked TAD as the BCS of cows milked OAD was higher than the BCS of cows milked TAD throughout lactation. This is consistent with Rémond et al. [34], Patton et al. [35], and McNamara et al. [36]. When cows are in improved energy balance, the utilization of LCFA from the adipose tissue could be lower and the synthesis of SCFA and MCFA could be higher as higher absorption of LCFA and inhibition of de novo synthesised FAs are indications of negative energy balance in dairy cows $[9,37]$. Generally, SCFA and MCFA, from FA C4:0 to C14:0 and some of C16:0, are produced by de novo synthesis inside the mammary gland, while some of C16:0 and the rest of LCFA are absorbed from feed and body fat reserves [38].

The proportion of SCFA, mainly C4:0 and C6:0, was lower in cows milked OAD. SCFA are the intermediate products released by the acyl transferase enzyme, which adds two carbon units from malonyl-CoA until the chain length reaches C16 [39]. Delamaire and Guinard-Flament [24] reported the lower proportion of de novo synthesised FAs could be due to a decline in the uptake of acetate and beta-hydroxy butyrate (precursors of de novo synthesis) by the mammary gland. However, in this study, the proportions of the majority of de novo synthesised FAs did not reduce, except the proportions of C4:0 and C6:0. It is possible that OAD milking could have reduced the activity of this enzyme due to the physiological changes in the mammary gland which could result in the lower proportion of SCFA. However, the consistency of MCFA suggests that acyl transferase elongation is still occurring to the same extent in cows milked OAD. It is evident that further studies should be carried out to study enzyme activity on FA synthesis in cows milked OAD.

When the cows are in negative energy balance, the absorption of LCFA is mainly from adipose tissue $[37,40]$. Oleic acid is a primary FA in adipocytes, so it is to be expected that its proportion will be higher in milk when cows are in negative energy balance $[33,41]$. A lower proportion of oleic acid (C18:0 cis-9) in milk from cows milked OAD compared to cows milked TAD also shows the reduced use of body reserves and improved energy balance in these cows. The higher proportions of de novo synthesised FAs (from C8:0 to C14:0) in cows milked OAD also confirm the improved energy balance of these animals. In this study, the cows milked TAD were in negative energy balance compared to cows milked OAD, which led to a higher proportion of LCFA [9]. This higher uptake of LCFA may inhibit the activity of the acetyl-CoA carboxylase enzyme which converts acetyl-CoA into malonyl-CoA during the process of de novo synthesis [42]. This inhibitory action could be a reason for lower proportions of de novo synthesised FAs (C8:0 to C14:0) in milk from TAD milking.

In a short-term trial with Holstein cows in EL, Delamaire and Guinard-Flament [24] reported lower levels of de novo synthesised FAs due to a lower mammary uptake of acetate and beta-hydroxybutyrate when milk was stored in the udder for $24 \mathrm{~h}$. When cows are milked OAD for longer periods, they may adapt physiologically to the MF, with the mammary gland applying different mechanisms for nutrient extraction for different MFs [24]. It has been suggested that OAD milking does not alter milk fatty acid composition in cows which are in energy balance [43]. However, in the present study, energy balance associated with MF significantly changed the FA composition of cows milked OAD compared to cows milked TAD. Because of these inconsistent findings, it would be useful to 
undertake further research to understand more about the mammary uptake of precursors and mechanism of FA synthesis in milk of cows milked OAD.

\subsection{The Effect of Stage of Lactation on Milk Production and Gross Milk Composition}

Daily yields of milk, fat, protein and lactose decreased linearly as lactation progressed in both MFs. Similar results were observed by Auldist et al. [44] in cows milked TAD under New Zealand grazing conditions.

Cows milked OAD showed reduced daily yields of milk, fat, protein and lactose compared to cows milked TAD throughout lactation. In cows milked OAD, the reduction in daily yields of milk, protein and lactose was significantly greater in EL. The reduction in daily FY was significantly higher in LL. Similarly, Stelwagen and Knight [29] reported a greater reduction in yield in EL than LL in cows milked OAD. The reduction in daily MY in cows milked OAD was lower in ML than in EL and LL. Daily MY reductions of 40\% and 29\% were reported in EL in cows milked OAD by Rémond et al. [45] in a 6-week and O'Brien et al. [20] in a 10-week trials, respectively. In short-term lactation studies, greater reductions (21-22\%) in milk production were observed in ML relative to LL [26,46,47]. In this study, daily MY reduction in LL was two-fold that of Davis et al. [48], who reported a $13 \%$ yield reduction in LL in a 7-day OAD milking trial. This higher reduction in OAD milking is in agreement with Stelwagen et al. [14], who stated that pasture-based seasonal farming with limited supplementary feeding could have a greater reduction in MY in LL due to lower dry matter intake. These findings suggest that the reduction in milk production may depend on stage of lactation.

The fat and protein percentages significantly increased, and the lactose percentage decreased with advancing lactation in both OAD and TAD milking. Similar results were observed by Auldist et al. [44] in cows milked TAD. The increasing concentration of milk solids as lactation progressed may be due to a concentrating effect created by decreasing milk volume [44]. In EL, the percentages of fat and protein were $13 \%$ and $7 \%$ higher, respectively, and lactose percentage was $4 \%$ lower in cows milked OAD than cows milked TAD. During ML, fat and protein percentages were $22 \%$ and $11 \%$ greater, respectively, and lactose percentage was $6 \%$ lower in cows milked OAD than cows milked TAD. Similarly, Pomies et al. [19] reported higher fat and protein percentages in ML in cows milked OAD, but the values were lower ( $7 \%$ and $5 \%$, respectively) than in the current study. Similar trends were observed in LL, which were in agreement with Lacy-Hulbert et al. [48], O'Brien et al. [20], and Ferris et al. [49]. However, the percentage of fat increased by $26 \%$ in LL, which was the highest rise in cows milked OAD compared to cows milked TAD in the production season and greatest of the above studies. Modifications in milk composition in OAD milking compared to TAD have been suggested to occur due to the increased exchange of milk and extra-cellular fluid through the increasingly permeable mammary gland membrane [13].

\subsection{The Effect of Stage of Lactation on Fatty Acid Composition}

In the present study, results obtained on the effect of stage of lactation on fatty acid composition are in agreement with Back and Thomson [8], Kgwatalala et al. [50], and Stoop et al. [9] for cows milked TAD. Trends followed by proportions of SFA and UFA in cows milked OAD were similar to cows milked TAD and in agreement with the above studies. The proportion of SFA was significantly higher in ML than EL and LL in both MFs. The proportion of UFA followed the opposite trend to that of the proportion of SFA. In EL, the lower proportion of SFA suggests that the cow might be in negative energy balance [40] due to high milk production and inadequate dry matter intake. In ML, the cows tend to increase their energy balance, which could lead to an increase in the proportion of SFA. In EL, due to negative energy balance, higher mobilisation of oleic acid could take place, which could have led to the higher proportion of oleic acid [50] and UFA.

The proportion of SCFA decreased and the proportion of LCFA increased with as lactation progressed in cows milked OAD. The reason behind the lower proportion of SCFA 
in ML in cows milked OAD is not clear although the energy balance (linked to BCS) of the OAD milked cows is better in ML than EL. Proportions of SCFA and MCFA were higher in ML than EL and LL in cows milked TAD, which is in agreement with Stoop et al. [9], Gross et al. [33], and Schwendel et al. [51]. In EL, cows milked OAD may be in lower negative energy balance compared to cows milked TAD and they can continue the de novo synthesis in the mammary gland without inhibition by the higher absorption of LCFA (the proportion of LCFA was lower in EL). In cows milked TAD, due to negative energy balance in EL, the de novo synthesis of SCFA and MCFA may be reduced. The higher proportion of SCFA, mainly C4:0 and C6:0, in ML and LL in cows milked TAD compared to cows milked OAD could be explained by the variation in their synthesis pathway [42] and these pathways are less affected by the inhibitory effect of LCFA. C4:0 is produced by two pathways: directly from preform 4 carbon BHB and by the malonyl-CoA-independent pathway ( $\beta$-reduction pathway) by condensation of acetyl units [42]. The synthesis of C6:0 is also less affected by the inhibition effect due to the addition of only one acetyl unit by malonyl-CoA (longer acyl chains are more affected) [42]. The results of this study reveal that the effect of MF and stage of lactation on FA composition could be connected to the energy balance of cows [50].

The proportions of individual FAs in cow milk affect butter hardness and cheese coagulation properties. Cows milked OAD tend to produce harder butter (lower spreadability) compared to cows milked TAD due to higher proportions of FAs from C8:0 to $\mathrm{C} 14: 0$ and lower proportion of C18:1. MacGibbon [52] reported that these proportions of FAs would increase the solid fat content of milk fat at a temperature of $10{ }^{\circ} \mathrm{C}\left(\mathrm{SCF}_{10}\right)$, which increases the hardness of the butter. When the $\mathrm{SCF}_{10}$ is lower, the butter will be soft; and when it is higher, the butter will be hard [52]. However, a lower proportion of C16:0 in cows milked OAD tends to decrease the hardness of the butter [53]. Overall, there is probably little change in the hardness of the fat and subsequently little change in the spreadability of butter. The higher proportions of C8:0, C10:0 and C12:0 and lower proportion of C18:1n_9 in cows milked OAD may affect rennet coagulation properties as measured using a Formagraph. In particular, it may increase the curd firming rate, i.e., a shorter K20 time, and increase curd firmness after $60 \mathrm{~min}$ (A60 parameter) [2]. While the fatty acid composition due to OAD milking may affect the cheese yield compared to TAD milking, Auldist et al. [2] reported that the relationships between fatty acid composition and cheese coagulation parameters were too weak to make consistent predictions. Of more commercial interest, the higher percentages of fat and protein in milk from cows milked $\mathrm{OAD}$ are likely to increase the weight of curd produced from a given volume of milk in the cheese-making process [3]. This would result in an increase in the capacity of an existing cheese plant, but this must be traded off against the reduced fat and protein yields per cow.

In New Zealand, the seasonal calving is synchronised with the season of the year, pasture growth and stages of lactation. It is difficult to distinguish to what extent the season, stage of lactation, or the interaction of both affect the proportions of FAs in milk [51]. Auldist et al. [44] found significant interaction between the season of the year and stage of lactation for milk fatty acid profile. However, in the present study, only the effect of stage of lactation on FA profile was studied and the season of the year was not investigated. In addition, this study discusses the de novo synthesised FAs more as they are less affected by the feed, and mainly a precursor- and enzyme-dependent pathway [38] in the mammary gland. One of the factors which affects the proportions of these FAs is the energy balance of cows, and the energy balance is affected by MF and level of feed intake.

\section{Conclusions}

Cows milked OAD had a significantly lower daily yield of milk and higher percentages of fat and protein compared with cows milked TAD. Cows milked OAD produced milk with significantly higher proportions of de novo synthesised FAs and lower proportion of LCFA compared to cows milked TAD. These finding suggest that the fatty acid composition of milk is significantly affected by MF with relation to the energy balance of cows. However, 
the confounding effect of feed was the limitation of this study. The findings of this study would be useful in selecting OAD milk for processing into dairy products. Further research would be useful to explore the effect of OAD milking on the mechanism of FA synthesis in cows milked OAD.

Author Contributions: I.S., N.L.-V., H.T.B., P.W.M.J., S.E.H. and A.K.H.M. contributed to the conceptualization, methodology, software, validation, formal analysis, investigation, data curation, original draft preparation, review and editing. N.L.-V., H.T.B., P.W.M.J., S.E.H. and A.K.H.M. contributed to the supervision, project administration, and funding acquisition. All authors have read and agreed to the published version of the manuscript.

Funding: This research was funded by Massey University and Inthujaa Sanjayaranj was sponsored by AHEAD Scholarship, Sri Lanka.

Institutional Review Board Statement: The ethical review and approval were waived as this study did not directly deal with the animals, instead collected milk from the milking parlor as the usual routine of herd-testing.

Informed Consent Statement: Not applicable.

Data Availability Statement: Not applicable.

Conflicts of Interest: The authors declare no conflict of interest.

\section{References}

1. Dalgleish, D.G. Bovine milk protein properties and the manufacturing quality of milk. Livest. Prod. Sci. 1993, 35, 75-93. [CrossRef]

2. Auldist, M.J.; Johnston, K.A.; White, N.J.; Fitzsimons, W.P.; Boland, M.J. A comparison of the composition, coagulation characteristics and cheesemaking capacity of milk from Friesian and Jersey dairy cows. J. Dairy Sci. 2004, 71, 51-57. [CrossRef] [PubMed]

3. Amenu, B.; Deeth, H.C. The impact of milk composition on cheddar cheese manufacture. Aust. J. Dairy Technol. 2007, 62, 171-184.

4. MacGibbon, A.K.H.; Taylor, M.M. Composition and structure of bovine milk lipids. In Advanced Dairy Chemistry, 3rd ed.; Fox, P.F., McSweeney, P.L.H., Eds.; Springer: New York, NY, USA, 2006; Volume 2, pp. 1-42.

5. Grummer, R.R. Effect of feed on the composition of milk fat. J. Dairy Sci. 1991, 74, 3244-3257. [CrossRef]

6. Bauman, D.E.; Griinari, J.M. Nutritional regulation of milk fat synthesis. Annu. Rev. Nutr. 2003, 23, 203-227. [CrossRef]

7. Palladino, R.A.; Buckley, F.; Prendiville, R.; Murphy, J.J.; Callan, J.; Kenny, D.A. A comparison between Holstein-Friesian and Jersey dairy cows and their F1 hybrid on milk fatty acid composition under grazing conditions. J. Dairy Sci. 2010, 93, $2176-2184$. [CrossRef]

8. Back, P.J.; Thomson, N.A. Exploiting cow genotype to increase milk value through production of minor milk components. Proc. N. Z. Soc. Anim. Prod. 2005, 65, 53-58.

9. Stoop, W.M.; Bovenhuis, H.; Heck, J.M.L.; van Arendonk, J.A.M. Effect of lactation stage and energy status on milk fat composition of Holstein-Friesian cows. J. Dairy Sci. 2009, 92, 1469-1478. [CrossRef]

10. Arnould, V.M.R.; Hammami, H.; Soyeurt, H.; Gengler, N. Short communication: Genetic variation of saturated fatty acids in Holsteins in the Walloon region of Belgium. J. Dairy Sci. 2010, 93, 4391-4397. [CrossRef]

11. Lucey, J. Cheesemaking from grass based seasonal milk and problems associated with late-lactation milk. Int. J. Dairy Technol. 1996, 49, 59-64. [CrossRef]

12. Tong, M.J.; Clark, D.A.; Cooper, C.V. Once-a-day milking: Possible and profitable? Proc. N. Z. Grassl. Assoc. 2002, 64, 33-37. [CrossRef]

13. Davis, S.R.; Farr, V.C.; Stelwagen, K. Regulation of yield loss and milk composition during once-daily milking: A review. Livest. Prod. Sci. 1999, 59, 77-94. [CrossRef]

14. Stelwagen, K.; Phyn, C.V.V.; Davis, S.R.; Guinard-Flament, J.; Pomiès, D.; Roche, J.R.; Kay, J.K. Invited review: Reduced milking frequency. Milk production and management implications. J. Dairy Sci. 2013, 96, 1-13. [CrossRef] [PubMed]

15. Rémond, B.; Pomiès, D.; Dupont, D.; Chilliard, Y. Once-a-day milking of multiparous Holstein cows throughout the entire lactation: Milk yield and composition, and nutritional status. Anim. Res. 2004, 53, 201-212. [CrossRef]

16. Clark, D.A.; Phyn, C.V.C.; Tong, M.J.; Collis, S.J.; Dalley, D.E. A systems comparison of once-versus twice daily milking of pastured dairy cows. J. Dairy Sci. 2006, 89, 1854-1862. [CrossRef]

17. Davis, S.R.; Turner, S.A.; Obolonkin, V.; Tiplady, K.; Spelman, R.J.; Phyn, C.V. Lactation traits associated with short-and long-term once-daily milking performance in New Zealand crossbred dairy cattle. J. Dairy Sci. 2015, 98, 6094-6107. [CrossRef]

18. Martin, B.; Pomies, D.; Pradel, P.; Verdier-Metz, I.; Rémond, B. Yield and sensory properties of cheese made with milk from Holstein or Montbéliarde cows milked twice or once daily. J. Dairy Sci. 2009, 92, 4730-4737. [CrossRef]

19. Pomies, D.; Martin, B.; Chilliard, Y.; Pradel, P.; Rémond, B. Once-a-day milking of Holstein and Montbéliarde cows for 7 weeks in mid-lactation. Animal 2007, 1, 1497-1505. [CrossRef] 
20. O'Brien, B.; Ryan, G.; Meaney, W.J.; McDonagh, D.; Kelly, A. Effect of frequency of milking on yield, composition, and processing quality of milk. J. Dairy Res. 2002, 69, 367-374. [CrossRef]

21. Sukhija, P.S.; Palmquist, D.L. Rapid method for determination of total fatty acid content and composition of feedstuffs and feces J. Agric. Food Chem. 1988, 36, 1202-1206. [CrossRef]

22. Dairy, N.Z. Body Condition Scoring Made Easy. 2004. Available online: https://www.dairynz.co.nz/media/5790783/bodycondition-scoring-made-easy-booklet.pdf (accessed on 16 September 2021).

23. Dairy, N.Z. Milking Is the Largest Labour Requirement on a Dairy Farm and the Timing of Milking Defines the Whole Structure of the Day. 2021. Available online: https:/ / www.dairynz.co.nz/milking/milking-intervals/\#: :text=The $\% 20$ three $\% 20 \mathrm{main} \% 20$ examples\%20of,(1\%20milking\%20per\%20day) (accessed on 7 October 2021).

24. Delamaire, E.; Guinard-Flament, J. Increasing milking intervals decreases the mammary blood flow and mammary uptake of nutrients in dairy cows. J. Dairy Sci. 2006, 89, 3439-3446. [CrossRef]

25. Pulido, E.; Fernández, M.; Prieto, N.; Baldwin, R.L.; Andrés, S.; López, S.; Giráldez, F.J. Effect of milking frequency and $\alpha$ tocopherol plus selenium supplementation on sheep milk lipid composition and oxidative stability. J. Dairy Sci. 2019, 102, 3097-3109. [CrossRef]

26. Carruthers, V.R.; Davis, S.R.; Bryant, A.M.; Henderson, H.V.; Morris, C.A.; Copeman, P.J. Response of Jersey and Friesian cows to once a day milking and prediction of response based on udder characteristics and milk composition. J. Dairy Sci. 1993, 60, 1-11. [CrossRef]

27. Grala, T.M.; Phyn, C.V.; Kay, J.K.; Rius, A.G.; Littlejohn, M.D.; Snell, R.G.; Roche, J.R. Temporary alterations to milking frequency, immediately post-calving, modified the expression of genes regulating milk synthesis and apoptosis in the bovine mammary gland. Proc. N. Z. Soc. Anim. Prod. 2011, 71, 3-8.

28. Littlejohn, M.D.; Walker, C.G.; Ward, H.E.; Lehnert, K.B.; Snell, R.G.; Verkerk, G.A.; Spelman, R.J.; Clark, D.A.; Davis, S.R. Effects of reduced frequency of milk removal on gene expression in the bovine mammary gland. Physiol. Genom. 2010, 41, 21-32. [CrossRef] [PubMed]

29. Stelwagen, K.; Knight, C.H. Effect of unilateral once or twice daily milking of cows on milk yield and udder characteristics in early and late lactation. J. Dairy Sci. 1997, 64, 487-494. [CrossRef]

30. Farr, V.C.; Stelwagen, K.; Kerr, M.A.; Davis, S.R. Effect of once daily milking (ODM) on enzyme activities in the bovine mammary gland. Proc. N. Z. Soc. Anim. Prod. 1995, 55, 12-13.

31. Dutreuil, M.; Guinard-Flament, J.; Boutinaud, M.; Hurtaud, C. Effect of duration of milk accumulation in the udder on milk composition, especially on milk fat globule. J. Dairy Sci. 2016, 99, 3934-3944. [CrossRef]

32. Ferlay, A.; Martin, B.; Lerch, S.; Gobert, M.; Pradel, P.; Chilliard, Y. Effects of supplementation of maize silage diets with extruded linseed, vitamin $\mathrm{E}$ and plant extracts rich in polyphenols, and morning vs evening milking on milk fatty acid profiles in Holstein and Montbéliarde cows. Animal 2010, 4, 627-640. [CrossRef]

33. Gross, J.; van Dorland, H.A.; Bruckmaier, R.M.; Schwarz, F.J. Milk fatty acid profile related to energy balance in dairy cows. J. Dairy Sci. 2011, 78, 479-488. [CrossRef]

34. Rémond, B.; Pomiès, D. Once-daily milking of dairy cows: A review of recent French experiments. Anim. Res. 2005, 54, 427-442. [CrossRef]

35. Patton, J.; Kenny, D.A.; Mee, J.F.; O'mara, F.P.; Wathes, D.C.; Cook, M.; Murphy, J.J. Effect of milking frequency and diet on milk production, energy balance, and reproduction in dairy cows. J. Dairy Sci. 2006, 89, 1478-1487. [CrossRef]

36. McNamara, S.; Murphy, J.J.; O'mara, F.P.; Rath, M.; Mee, J.F. Effect of milking frequency in early lactation on energy metabolism, milk production and reproductive performance of dairy cows. Livest. Sci. 2008, 117, 70-78. [CrossRef]

37. Bastin, C.; Gengler, N.; Soyeurt, H. Phenotypic and genetic variability of production traits and milk fatty acid contents across days in milk for Walloon Holstein first-parity cows. J. Dairy Sci. 2011, 94, 4152-4163. [CrossRef] [PubMed]

38. MacGibbon, A.K.H. Composition and Structure of Bovine Milk Lipids. In Advanced Dairy Chemistry, 4th ed.; McSweeney, P.L.H., Fox, P.F., O'Mahony, J.A., Eds.; Springer: New York, NY, USA, 2020; Volume 2, pp. 1-32.

39. Palmquist, D.L.; Harvatine, K.J. Origin of fatty acids and influence of nutritional factors on milk fat. In Advanced Dairy Chemistry, 4th ed.; McSweeney, P.L.H., Fox, P.F., O'Mahony, J.A., Eds.; Springer: New York, NY, USA, 2020; Volume 2, pp. 33-66.

40. Vranković, L.; Aladrović, J.; Octenjak, D.; Bijelić, D.; Cvetnić, L.; Stojević, Z. Milk fatty acid composition as an indicator of energy status in Holstein dairy cows. Arch. Anim. Breed. 2017, 60, 205-212. [CrossRef]

41. Rukkwamsuk, T.; Geelen, M.J.H.; Kruip, T.A.M.; Wensing, T. Interrelation of fatty acid composition in adipose tissue, serum, and liver of dairy cows during the development of fatty liver postpartum. J. Dairy Sci. 2000, 83, 52-59. [CrossRef]

42. Palmquist, D.L.; Beaulieu, A.D.; Barbano, D.M. Feed and animal factors influencing milk fat composition. J. Dairy Sci. 1993, 76, 1753-1771. [CrossRef]

43. Chilliard, Y.; Pomies, D.; Pradel, P.; Rémond, B. Once daily milking does not change milk fatty acid profile in cows in equilibrated energy balance. In Proceedings of the 57th Annual Meeting of the European Association for Animal Production (EAAP), Antalya, Turkey, 17-20 September 2006; Wageningen Academic Publishers: Wageningen, The Netherlands, 2006.

44. Auldist, M.J.; Walsh, B.J.; Thomson, N.A. Seasonal and lactational influences on bovine milk composition in New Zealand. J. Dairy Res. 1998, 65, 401-411. [CrossRef] 
45. Rémond, B.; Coulon, J.B.; Nicloux, M.; Levieux, D. Effect of temporary once-daily milking in early lactation on milk production and nutritional status of dairy cows. Ann. Zootech. 1999, 48, 341-352. Available online: https://hal.archives-ouvertes.fr/hal-00889807 (accessed on 1 November 2021). [CrossRef]

46. Davis, S.R.; Farr, V.C.; Stelwagen, K. Once daily milking of dairy cows: An appraisal. Proc. N. Z. Soc. Anim. Prod. 1998, 58, 36-40.

47. Davis, S.; McNaughton, L.; Bracefield, G.; Sanders, K.; Spelman., R. Variation in milk yield response to once-daily milking in Friesian-Jersey crossbred cattle. J. Dairy Sci. 2006, 89, 146-147.

48. Lacy-Hulbert, S.J.; Woolford, M.W.; Nicholas, G.D.; Prosser, C.G.; Stelwagen, K. Effect of milking frequency and pasture intake on milk yield and composition of late lactation cows. J. Dairy Sci. 1999, 82, 1232-1239. [CrossRef]

49. Ferris, C.P.; Frost, J.P.; Mayne, C.S.; McCoy, M.A.; Kilpatrick, D.J. A comparison of the direct and residual response of dairy cows to once or twice-daily milking, in late lactation. Livest. Sci. 2008, 114, 305-314. [CrossRef]

50. Kgwatalala, P.M.; Ibeagha-Awemu, E.M.; Mustafa, A.F.; Zhao, X. Stearoyl-CoA desaturase 1 genotype and stage of lactation influences milk fatty acid composition of Canadian Holstein cows. Anim. Genet. 2009, 40, 609-615. [CrossRef] [PubMed]

51. Schwendel, B.H.; Morel, P.C.; Wester, T.J.; Tavendale, M.H.; Deadman, C.; Fong, B.; Shadbolt, N.M.; Thatcher, A.; Otter, D.E. Fatty acid profile differs between organic and conventionally produced cow milk independent of season or milking time. J. Dairy Sci. 2015, 98, 1411-1425. [CrossRef] [PubMed]

52. MacGibbon, A.K. Herd-to-herd variations in the properties of milkfat. Proc. N. Z. Soc. Anim. Prod. 1996, 56, $224-227$.

53. Mackle, T.R.; Petch, S.F.; Bryant, A.M.; Auldist, M.J.; Henderson, H.V.; MacGibbon, A.K.H. Variation in the characteristics of milkfat from pasture-fed dairy cows during late spring and the effects of grain supplementation. N. Z. J. Agric. Res. 1997, 40, 349-359. [CrossRef] 